\title{
Chemical analysis and biorefinery of red algae Kappaphycus alvarezii for efficient production of glucose from residue of carrageenan extraction process
}

Fernando Masarin ${ }^{1 *}$, Fernando Roberto Paz Cedeno ${ }^{1}$, Eddyn Gabriel Solorzano Chavez ${ }^{1}$, Levi Ezequiel de Oliveira ${ }^{3}$, Valéria Cress Gelli ${ }^{4}$ and Rubens Monti ${ }^{2}$

\begin{abstract}
Background: Biorefineries serve to efficiently utilize biomass and their by-products. Algal biorefineries are designed to generate bioproducts for commercial use. Due to the high carbohydrate content of algal biomass, biorefinery to generate biofuels, such as bioethanol, is of great interest. Carrageenan is a predominant polysaccharide hydrocolloid found in red macroalgae and is widely used in food, cosmetics, and pharmaceuticals. In this study, we report the biorefinery of carrageenan derived from processing of experimental strains of the red macroalgae Kappaphycus alvarezii. Specifically, the chemical composition and enzymatic hydrolysis of the residue produced from carrageenan extraction were evaluated to determine the conditions for efficient generation of carbohydrate bioproducts.

Results: The productivity and growth rates of $K$. alvarezii strains were assessed along with the chemical composition (total carbohydrates, ash, sulfate groups, proteins, insoluble aromatics, galacturonic acid, and lipids) of each strain. Two strains, brown and red, were selected based on their high growth rates and productivity and were treated with $6 \%$ $\mathrm{KOH}$ for extraction of carrageenan. The yields of biomass from treatment with $6 \% \mathrm{KOH}$ solution of the brown and red strains were 89.3 and $89.5 \%$, respectively. The yields of carrageenan and its residue were 63.5 and $23 \%$, respectively, for the brown strain and 60 and $27.8 \%$, respectively, for the red strain. The residues from the brown and red strains were assessed to detect any potential bioproducts. The galactan, ash, protein, insoluble aromatics, and sulfate groups of the residue were reduced to comparable extents for the two strains. However, $\mathrm{KOH}$ treatment did not reduce the content of glucan in the residue from either strain. Glucose was produced by enzymatic hydrolysis for $72 \mathrm{~h}$ using both strains. The glucan conversion was $100 \%$ for both strains, and the concentrations of glucose from the brown and red strains were 13.7 and $11.5 \mathrm{~g} \mathrm{~L}^{-1}$, respectively. The present results highlight the efficiency of generating a key bioproduct from carrageenan residue.
\end{abstract}

Conclusions: This study demonstrates the potential for glucose production using carrageenan residue. Thus, the biorefinery of $K$. alvarezii can be exploited not only to produce carrageenan, but also to generate glucose for future use in biofuel production.

Keywords: Kappaphycus alvarezii, Chemical composition, Carrageenan, Residue, Digestibility, Glucose, Bioproducts

\footnotetext{
*Correspondence: fmasarin@fcfar.unesp.br

1 Departamento de Bioprocessos e Biotecnologia, Faculdade de Ciências

Farmacêuticas-FCF, UNESP-Univ Estadual Paulista, 14800-903 Araraquara,

SP, Brazil

Full list of author information is available at the end of the article
} 


\section{Background}

The use of algal biomass as feedstock for the food, cosmetics, nutraceutical, pharmaceutical, biofertilizer, and biofuel industries is of great interest and is an actively investigated field of research [1-4]. The concept of utilizing algae in biorefineries is a promising and economically viable alternative for the production of bioproducts, such as those crucial to biofuel production. Moreover, the cultivation of algae offers environmental appeal since growing biomass captures $\mathrm{CO}_{2}$, a greenhouse gas (GHG), from the atmosphere via photosynthesis. These carbon sinks can help to mitigate global warming (GW) [5-8]. Algae also produce more oxygen than consumed in respiration, unlike terrestrial plants. Furthermore, the production of cultivated algae is $22 \mathrm{~kg} \mathrm{~m}^{2}$ year $^{-1}$ compared to land plants, with an average production of 0.5-4.4 $\mathrm{kg} \mathrm{m}^{2}$ year $^{-1}$ [8-10]. Thus, algal biomass is poised to provide many environmental and economic benefits.

Marine macroalgae can be classified into three major groups based on the lack or presence of phytopigments other than chlorophyll: brown algae (Phaeophyceae), green algae (Chlorophyceae), and red algae (Rhodophyceae) $[11,12]$. Brown macroalgae comprises almost 1800 species with an olive-green to dark brown color derived from an abundance of fucoxanthin, a yellow-brown pigment that masks the green color of chlorophyll. The composition of brown macroalgae such as Laminaria includes up to $55 \%$ dry weight of carbohydrates including alginate, cellulose, laminarin that can be easily hydrolyzed by laminarase (endo-1,3(4)- $\beta$-glucanase) and cellulases (endo-1,4(4)- $\beta$-glucanase) to release glucose monomers [11-13]. Green macroalgae include almost 1500 species, and are primarily composed of starch for food reserves with cellulose and pectin as the main structural polysaccharides in the cell wall $[11,12]$. Red macroalgae comprise almost 6000 species of algae having a characteristic red or pink color derived from the pigments phycocyanin and phycoerythrin, which allow growth in relatively deep waters. The composition of red macroalgae varies from species to species but generally comprises cellulose, glucan, and galactan. The cell wall of red seaweed is constructed of cellulose and two kinds of long-chain structural polysaccharides that are valued for their gelforming ability, i.e., agar and carrageenan. Agar can be readily hydrolyzed to release the galactose subunits. Carrageenan can be classified as lambda (l), kappa (k), or iota (i) based on the-gel-forming ability and is used mainly for thickening foods such as yogurt, ice cream, and pudding $[11,12]$.

The replacement of fossil fuels with biofuels derived from algae reduces GHG emissions from transportation $[14,15]$. The high potential for production of biofuel production from algae is due to the considerable amounts of carbohydrates (found especially in macroalgae) and oil (found especially in microalgae) in these species, thus making algal biomass an excellent resource for bioethanol and biodiesel production [16-18].

Second generation biofuels based on waste biomass do not compete directly with food sources, and are thus advantageous alternatives to first generation biofuels that require large areas of farmland to dually provide food and biomass for fuel production. However, the pre-treatment phase required to convert complex carbohydrates into fermentable sugars results in low yield and high cost and serves as a technological bottleneck $[19,20]$. Indeed, this challenge can be resolved using algae since the algal cell wall is virtually free of structural biopolymers such as lignin and hemicellulose (a branched carbohydrate polymer). The elimination of chemical pre-treatment steps results in minimized recalcitrance of the biomaterial and enables direct enzymatic hydrolysis of polysaccharide fractions, resulting in monomeric sugars [21].

In addition, other bioproducts can be extracted from macroalgae, such as agar, carrageenan, and alginate hydrocolloids, which are all extensively used as viscosity modifying agents in foods and cosmetic products [22]. Populations from the Scandinavian Peninsula first used carrageenan, a polysaccharide of galactose obtained from the red macroalgae Kappaphycus alvarezii more than five centuries ago, as a food source [22-24]. Moreover, there is recent research describing the potential of carrageenan for bioethanol production due to its high galactose content [25-30]. Biofuels produced from macroalgae are considered third generation [25-30]. However, because carrageenan is used as a food source, its use as a fuel source brings up the food versus fuel dilemma, thereby raising the challenge to find additional yet efficient uses of this valuable bioproduct.

The aim of this study is to evaluate the chemical composition of $K$. alvarezii strains and the potential digestibility of the residue generated from carrageenan processing for the production of monomeric sugar bioproducts.

\section{Methods}

\section{Raw material and biomass preparation}

Four different $K$. alvarezii seaweed strains were used. The strains were obtained from the Fisheries Institute, Ubatuba, São Paulo (SP). The following $K$. alvarezii strains were used: brown, red, green, and G11. The strains were grown during May and June of 2013. The $K$. alvarezii strains were grown in the Atlantic Ocean in the experimental field base at Itaguá beach in Ubatuba, SP, Brazil (GPS coordinates $23^{\circ} 27^{\prime} 5,8^{\prime \prime} \mathrm{S} ; 45^{\circ} 02^{\prime} 49,3^{\prime \prime} \mathrm{W}$ ). The structure used to grow the seaweed strains consisted of a raft anchored in the bay [31,32]. Ten shoots of vegetative 
growth from each strain (approximately $70 \mathrm{~g}$ on wet basis) were pre-weighed and bound on a nylon line in a subassembly on the surface of the seawater, which provided a cultivation density of 6.7 plants per $\mathrm{m}^{2}$. For cultivation, the strains remained in the structure for 30 days. After 30 days, the strains were weighed again. The wet weight and dry mass from each strain were determined using an average humidity of $35 \%$ (commercial value) [30,31]. The growth rate was calculated according to the equation: Growth rate $($ percentage on day -1$)=\left[\left(w_{t} / w_{0}\right) 1 / t-1\right]$ $* 100$, where $w_{t}$ is the final wet mass $(\mathrm{g}) ; w_{0}$ is the initial wet mass ( $\mathrm{g}$ ); and $t$ is the cultivation time (30 days) [32, 33]. The productivity was calculated according to the equation: Productivity $\left(\mathrm{gm}^{2}\right.$ day $\left.^{-1}\right)(w / w$, dry basis $)=$ $[(\mathrm{dwtf}-\mathrm{dwti}) / t *(\mathrm{dwt} / \mathrm{wwt})] / A$, where dwtf is the final dry mass (g); dwti is the initial dry mass $(\mathrm{g}) ; t$ is the cultivation time (30 days); dwt = total dry mass; wwt is the total wet mass and $A$ is the total area of cultivation [32, 33]. After collection, the biomass was dried at $25^{\circ} \mathrm{C}$. The biomass was washed with distilled water, with stirring, in a $10 \mathrm{~L}$ polypropylene beaker for $45 \mathrm{~min}$ at a ratio of $35 \mathrm{~g}$ (dry weight) of macroalgae biomass to $1 \mathrm{~L}$ of distilled water. After washing, the solution was removed using a sieve with a $1 \mathrm{~mm}$ screen. Washing was repeated until the electrical conductivity of the wash solution was similar to that of distilled water (measured with a portable conductivity meter). After washing, the samples were again dried at $25^{\circ} \mathrm{C}$. These materials are hereafter termed 'untreated material.'

\section{Chemical composition of the samples}

Hexane-soluble extractives were determined by extraction with $99 \%(\mathrm{v} / \mathrm{v})$ hexane in a Soxhlet apparatus [26]. The samples were air dried, milled, and passed through a $0.84 \mathrm{~mm}$ screen. Approximately, $1 \mathrm{~g}$ of the milled sample was extracted with $99 \%$ hexane for $8 \mathrm{~h}$ in the Soxhlet apparatus. The percentage of lipids was determined based on the dry weights of the extracted and non-extracted milled samples [data provided as mean \pm standard deviation (SD)]. This procedure was conducted in triplicate.

The milled samples were hydrolyzed with $72 \%(\mathrm{w} / \mathrm{w})$ sulfuric acid at $30{ }^{\circ} \mathrm{C}$ for $1 \mathrm{~h} \mathrm{(} 3 \mathrm{~mL}$ of acid to $300 \mathrm{mg}$ of sample) as described previously [34,35]. The acid hydrolysate was diluted with $79 \mathrm{~mL}$ of distilled water $(4 \%(\mathrm{w} / \mathrm{w})$ sulfuric acid), and the mixture was autoclaved at $121{ }^{\circ} \mathrm{C}$ for $1 \mathrm{~h}$. The residual material was cooled and filtered through a porous glass filter (Scott number 3, Germany). The solids were dried to a constant weight at $105^{\circ} \mathrm{C}$ and were assessed as the insoluble aromatics component. The filtrate was further passed through $0.45 \mu \mathrm{m}$ membranes. The total sugar content in the same solution was determined by the sulfuric acid/phenol method, using sucrose as the calibration standard [36]. The filtrates were evaluated via HPLC/MS analysis (using HPLC Agilent 1200 Series and AB Sciex QTRAP mass spectrometers) to confirm the presence of monomeric sugars. Detection of the monomeric sugars in the soluble fraction was performed using HPX87P columns (Bio-Rad; Hercules, CA, USA) at $80^{\circ} \mathrm{C}$ by elution with water at a rate of $0.6 \mathrm{~mL} \mathrm{~min}^{-1}$. The mass spectrometer was operated using electrospray ionization (ESI) in positive and negative modes. The ionization source parameters in negative mode were: ion spray: $-4500 \mathrm{~V}$; curtain gas: $15 \mathrm{psi}$; temperature: $650{ }^{\circ} \mathrm{C}$; gas 1:50 psi; gas 2:50 psi; and heater interface: on. The ionization source parameters in the positive mode were as follows: ion spray: $5500 \mathrm{~V}$; curtain gas: 15 psi; temperature: $650{ }^{\circ} \mathrm{C}$; gas 1:50 psi; gas 2:50 psi; heater interface: on. The standards were diluted to $1 \mathrm{mg} \mathrm{L}^{-1}$ in water with $0.1 \%$ acetic acid, and the optimization was performed by direct infusion into the automatic flow $\left(10 \mathrm{~L} \mathrm{~min}^{-1}\right)$ using a syringe. All sugars were detected as water adducts $(+18)$ $[\mathrm{M}+18]^{+}$in positive mode. Xylose: (SRM1, Q1 $=168.1$, $\mathrm{Q} 3=150.0$, DwellTime $(\mathrm{ms})=250, \mathrm{SD}(\mathrm{V})=16$, $\mathrm{EP}(\mathrm{V})=5, \mathrm{CEP}(\mathrm{V})=10, \mathrm{EC}(\mathrm{V})=9$ and $\mathrm{CXP}(\mathrm{V})=4)$; $(\mathrm{SRM} 2, \mathrm{Q} 1=168.1, \mathrm{Q} 3=73.2$, DwellTime $(\mathrm{ms})=250$, $\mathrm{SD}(\mathrm{V})=16, \mathrm{EP}(\mathrm{V})=5, \mathrm{CEP}(\mathrm{V})=10, \mathrm{EC}(\mathrm{V})=19$ and $\operatorname{CXP}(\mathrm{V})=4$. Arabinose: $(\mathrm{SRM} 1, \mathrm{Q} 1=168.1, \mathrm{Q} 3=50.1$, DwellTime $(\mathrm{ms})=250, \mathrm{SD}(\mathrm{V})=6, \mathrm{EP}(\mathrm{V})=3.5$, $\mathrm{CEP}(\mathrm{V})=14, \mathrm{EC}(\mathrm{V})=9$ and $\mathrm{CXP}(\mathrm{V})=4)$, (SRM2, $\mathrm{Q} 1=168.1, \mathrm{Q} 3=73.2$, DwellTime $(\mathrm{ms})=250$, $\mathrm{SD}(\mathrm{V})=16, \mathrm{EP}(\mathrm{V})=5, \mathrm{CEP}(\mathrm{V})=10, \mathrm{EC}(\mathrm{V})=19$ and $\operatorname{CXP}(\mathrm{V})=4 ;(\mathrm{SRM} 2, \mathrm{Q} 1=168.1, \mathrm{Q} 3=73.0$, DwellTime $(\mathrm{ms})=250, \mathrm{SD}(\mathrm{V})=16, \mathrm{EP}(\mathrm{V})=3.5$, $\mathrm{CEP}(\mathrm{V})=14 \mathrm{EC}(\mathrm{V})=21$ and $\mathrm{CXP}(\mathrm{V})=4$ cellobiose: $($ SRM 1, Q1 $=360.2$, Q3 = 163.2, DwellTime $(\mathrm{ms})=250$, $\mathrm{SD}(\mathrm{V})=21, \mathrm{EP}(\mathrm{V})=4.5, \mathrm{CEP}(\mathrm{V})=16, \mathrm{EC}(\mathrm{V})=17$ and $\operatorname{CXP}(\mathrm{V})=4),(\mathrm{SRM} 2, \mathrm{Q} 1=360.2, \mathrm{Q} 3=84.9$, DwellTime $(\mathrm{ms})=250, \mathrm{SD}(\mathrm{V})=21, \mathrm{EP}(\mathrm{V})=4.5$, $\mathrm{CEP}(\mathrm{V})=16, \mathrm{EC}(\mathrm{V})=33$ and $\mathrm{CXP}(\mathrm{V})=4$ Galactose: (SRM1, Q1 = 198.0, Q3 = 163.1, DwellTime (ms) $=250$, $\mathrm{SD}(\mathrm{V})=21, \mathrm{EP}(\mathrm{V})=6, \mathrm{CEP}(\mathrm{V})=12, \mathrm{EC}(\mathrm{V})=11$ and $\mathrm{CXP}(\mathrm{V})=4),(\mathrm{SRM} 2, \mathrm{Q} 1=198.0, \mathrm{Q} 3=91.2$, DwellTime $(\mathrm{ms})=250, \mathrm{SD}(\mathrm{V})=21, \mathrm{EP}(\mathrm{V})=6$, $\operatorname{CEP}(\mathrm{V})=12, \mathrm{EC}(\mathrm{V})=19$ and $\operatorname{CXP}(\mathrm{V})=4$ Glucose: $(\mathrm{SRM} 1, \mathrm{Q} 1=198.1, \mathrm{Q} 3=85.1$, DwellTime $(\mathrm{ms})=250$, $\mathrm{SD}(\mathrm{V})=16, \mathrm{EP}(\mathrm{V})=6.5, \mathrm{CEP}(\mathrm{V})=10, \mathrm{EC}(\mathrm{V})=21$ and $\operatorname{CXP}(\mathrm{V})=4),(\mathrm{SRM} 2, \mathrm{Q} 1=198.1, \mathrm{Q} 3=163.2$, DwellTime $(\mathrm{ms})=250, \mathrm{SD}(\mathrm{V})=16, \mathrm{EP}(\mathrm{V})=6.5$, $\mathrm{CEP}(\mathrm{V})=10, \mathrm{EC}(\mathrm{V})=11$ and $\operatorname{CXP}(\mathrm{V})=4$. Mannose: $($ SRM1, Q1 $=198.1, \mathrm{Q} 3=163.2$, DwellTime $(\mathrm{ms})=250$, $\mathrm{SD}(\mathrm{V})=21, \mathrm{EP}(\mathrm{V})=8, \mathrm{CEP}(\mathrm{V})=12, \mathrm{EC}(\mathrm{V})=11$ and $\operatorname{CXP}(\mathrm{V})=4) ;(\mathrm{SRM} 2, \mathrm{Q} 1=198.1, \mathrm{Q} 3=85$, DwellTime $(\mathrm{ms})=250, \mathrm{SD}(\mathrm{V})=21, \mathrm{EP}(\mathrm{V})=8$, $\mathrm{CEP}(\mathrm{V})=12, \mathrm{EC}(\mathrm{V})=25$ and $\operatorname{CXP}(\mathrm{V})=4$. Rhamnose: 
(SRM1, Q1 = 198.1, Q3 = 163.2, DwellTime $(\mathrm{ms})=250$, $\mathrm{SD}(\mathrm{V})=21, \mathrm{EP}(\mathrm{V})=8, \mathrm{CEP}(\mathrm{V})=12, \mathrm{EC}(\mathrm{V})=11$ and $\mathrm{CXP}(\mathrm{V})=4,(\mathrm{SRM} 2, \mathrm{Q} 1=198.1, \mathrm{Q} 3=85$, DwellTime $(\mathrm{ms})=250, \mathrm{SD}(\mathrm{V})=21, \mathrm{EP}(\mathrm{V})=8$, $\mathrm{CEP}(\mathrm{V})=12, \mathrm{EC}(\mathrm{V})=25$ and $\mathrm{CXP}(\mathrm{V})=4$. Galacturonic acid was detected as $[\mathrm{M}-\mathrm{H}]^{-}$in negative mode. Galacturonic acid: (SRM1, Q1 = 193.02, $\mathrm{Q} 3=113$, DwellTime $(\mathrm{ms})=2500, \mathrm{SD}(\mathrm{V})=-20$, $\mathrm{EP}(\mathrm{V})=-3.5, \mathrm{CEP}(\mathrm{V})=-10, \mathrm{EC}(\mathrm{V})=-18$ and $\mathrm{CXP}(\mathrm{V})=-2),(\mathrm{SRM} 2, \mathrm{Q} 1=193.021, \mathrm{Q} 3=59.1$, DwellTime $(\mathrm{ms})=2500, \mathrm{SD}(\mathrm{V})=-20, \mathrm{EP}(\mathrm{V})=-3.5$, $\mathrm{CEP}(\mathrm{V})=-10, \mathrm{EC}(\mathrm{V})=-26$ and $\mathrm{CXP}(\mathrm{V})=0$. The concentrations of monomeric sugars in the soluble fraction were determined by HPLC (HPX87P column; Bio-Rad, Hercules, CA, USA) at $80{ }^{\circ} \mathrm{C}$ using water as the eluent at

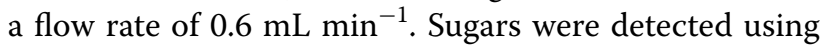
a temperature-controlled refractive index detector at $45{ }^{\circ} \mathrm{C}$. Glucose, xylose, mannose, and galactose were used as external calibration standards. Corrections were performed by considering the anhydrogalactose-degradation reactions that took place during acid hydrolysis. Under the present acid hydrolysis conditions, all the anhydrogalactose present in the sample is degraded [29, 37]. Thus, the anhydrogalactose content in the carrageenans and agars was calculated using the galactose to anhydrogalactose ratio of $1: 1.27[29,37]$. The factor used to convert the sugar monomers to anhydromonomers was 0.9 for glucose and galactose. This procedure was conducted in triplicate. Glucose was reported as glucan and galactose and anhydrogalactose as galactan after correction by the hydrolysis factor. The concentration of hydroxymethylfurfural and furfural in the soluble fractions was determined using an HPLC instrument equipped with a $250 \mathrm{~mm}$ long column with an outer diameter of $4 \mathrm{~mm}$ (Hypersil; Thermo-Scientific) using acetonitrile:water $(1: 8)$ containing $1 \%(\mathrm{v} / \mathrm{v})$ acetic acid as an eluent at a flow rate of $0.8 \mathrm{~mL} \mathrm{~min}^{-1}$. Hydroxymethylfurfural and furfural were detected at $276 \mathrm{~nm}$.

The sulfate group content of the samples was quantified using modified spectrophotometric methods [3840]. About $0.05 \mathrm{~g}$ of the milled sample was weighed and placed in test flasks. One milliliter of $0.5 \mathrm{~N} \mathrm{HCl}$ was added to each flask, and the flasks were capped with aluminum foil and autoclaved at $120^{\circ} \mathrm{C}$ for $1 \mathrm{~h}$ at $1 \mathrm{~atm}$. At the end of the reaction, the sample was transferred into $15 \mathrm{~mL}$ Falcon tubes. Water was then added to each tube to achieve a volume of $10 \mathrm{~mL}$ followed by centrifugation at $7000 \times g$ for $10 \mathrm{~min}$. The supernatant $(2 \mathrm{~mL}), 18 \mathrm{~mL}$ of distilled water, and $2 \mathrm{~mL}$ of $0.5 \mathrm{~N} \mathrm{HCl}$ were added to the test flasks and stirred for a few seconds. Afterwards, $1 \mathrm{~mL}$ of $\mathrm{BaCl}_{2}$ gelatin (Difco-Laboratories, Detroit, EUA) was added. The tubes were kept at $25^{\circ} \mathrm{C}$ for $30 \mathrm{~min}$ with stirring, and absorbance readings were taken at $550 \mathrm{~nm}$ (Genesys 10S, Thermo-Scientific).

The protein content of the samples was quantified using a Kjeldahl digester to determine the total nitrogen. The protein content was calculated using a nitrogen conversion factor of 6.25 [41]. The experiments were performed in triplicate. For quantification of the ash content of the samples [42], approximately $1 \mathrm{~g}$ of milled sample was weighed into a porcelain crucible and combusted in a muffle furnace at $575 \pm 25{ }^{\circ} \mathrm{C}$ for $3 \mathrm{~h}$ using a pre-programmed heating ramp. At the end of $3 \mathrm{~h}$, the pots were kept in the oven until the temperature was about $105^{\circ} \mathrm{C}$. The crucibles were cooled and weighed. The experiments were performed in duplicate. The metal content of the samples was also quantified by treating approximately $0.05 \mathrm{~g}$ of the milled sample with $1 \mathrm{~mL}$ of sulfuric acid and $2 \mathrm{~mL}$ of nitric acid in a glass digester at $150{ }^{\circ} \mathrm{C}$ until the solutions become clear. These solutions were allowed to swell in a $100 \mathrm{~mL}$ volumetric flask and analyzed using a spectrophotometer (ICP Optima Perkin Elmer Model 8000). The following metals were analyzed: manganese, calcium, sodium, copper, silicon, iron, and potassium. The experiments were performed in triplicate.

\section{Carrageenan processing for selected samples}

Two strains of previously selected $K$. alvarezii (brown and red, grown in May 2013) were processed and the semi-refined carrageenan was extracted; the residue from this extraction process was also analyzed. Prior to extraction of the semi-refined carrageenan, "cold" alkali transformation was performed [32, 38]. Briefly, approximately $8 \mathrm{~g}$ (dry weight) of macroalgae was soaked in $96 \mathrm{~mL}$ of $6 \% \mathrm{KOH}$ solution $(\mathrm{w} / \mathrm{v})$ for $24 \mathrm{~h}$ at $25{ }^{\circ} \mathrm{C}$ ("cold" alkali transformation). The material was copiously washed with water, sun bleached for $12 \mathrm{~h}$, and dried at $60{ }^{\circ} \mathrm{C}$ until constant weight was achieved. The material was weighed, milled, and passed through a $0.84 \mathrm{~mm}$ screen. Approximately, $3 \mathrm{~g}$ (dry weight) of the material obtained after alkaline transformation was extracted with $240 \mathrm{~mL}$ of distilled water in flasks and incubated at $65{ }^{\circ} \mathrm{C}$ for $2 \mathrm{~h}$ with rotary agitation at $120 \mathrm{rpm}$. The solution was then filtered using nylon tissue, and the extract was dried at $60{ }^{\circ} \mathrm{C}$ until constant weight was achieved (hereafter referred to as semirefined carrageenan). The material retained on the nylon tissue after filtering was recovered and dried to constant weight at $60{ }^{\circ} \mathrm{C}$ (hereafter referred to as residue). Both the semi-refined carrageenan and the residue were weighed. The yield from the alkali treatment was determined from the difference between the original (untreated material) and final weights (dry weight 
basis). The partial yield of the semi-refined carrageenan and residue was obtained from the difference between the initial weight [the material treated with $6 \% \mathrm{KOH}$ $(\mathrm{w} / \mathrm{v})]$ and final weight of semi-refined carrageenan and residue (dry weight basis). The overall yields of the semirefined carrageenan and residue were obtained from the difference between the original weight (untreated material) and final weight of the semi-refined carrageenan and residue (dry weight basis).

\section{Enzymatic hydrolysis of the selected samples}

Enzymatic hydrolysis was performed using commercial enzyme preparations (Cellic CTec II, Novozymes, Denmark) at a dosage of 10 FPU per gram of sample (dry weight basis), corresponding to $200 \mathrm{IU}$ of $\beta$-glucosidase. The total cellulases and $\beta$-glucosidase activity determined using the Celic CTec II extract were $92 \mathrm{FPU} \mathrm{mL}^{-1}$ and $1800 \mathrm{UI} \mathrm{mL}{ }^{-1}$, respectively. Each hydrolysis experiment was conducted in $50 \mathrm{~mL}$ Falcon tubes containing $200 \mathrm{mg}$ of milled sample (dry weight basis) and $10 \mathrm{~mL}$ of $50 \mathrm{mM}$ sodium-acetate buffer ( $\mathrm{pH} 4.8)$ in addition to the enzyme solution. The flasks were incubated at $45^{\circ} \mathrm{C}$ with rotary agitation at $120 \mathrm{rpm}$. The reaction was stopped at defined periods from 4 to $72 \mathrm{~h}$ by heating the flask to $100{ }^{\circ} \mathrm{C}$ for $5 \mathrm{~min}$, followed by centrifugation of the material at $7000 \times g$ for $10 \mathrm{~min}$. The soluble fractions were assayed for glucose using HPLC with an HPX87P column (Bio-Rad) at $45^{\circ} \mathrm{C}$ using water as an eluent at an elution rate of $0.6 \mathrm{~mL} \mathrm{~min}{ }^{-1}$. The sugars were detected using a temperature-controlled infrared detector set at $45{ }^{\circ} \mathrm{C}$. The glucan conversion level reported herein refers to the conversion of the polysaccharides to their monomers. Values (mean $\pm \mathrm{SD}$ ) for the hydrolysis of the samples were estimated from triplicate runs.

\section{Results and discussion \\ Productivity and chemical composition of different $K$. alvarezii strains}

The growth rate and productivity of different $K$. alvarezii strains were evaluated based on an experimental field test in Ubatuba, São Paulo (SP), Brazil (Fig. 1). The productivity ranged from 15.9 to $46.0 \mathrm{~g} \mathrm{~m}^{2} \mathrm{day}^{-1}$, and the growth rate ranged from 3.8 to $6.2 \%$ day $^{-1}$ (Fig. 1). The G11 strain showed the lowest productivity and growth rate of the evaluated strains. The brown and red strains grown in May 2013 showed higher productivity than the brown and red strains grown in June 2013. The average data presented were similar to those reported in the literature and the values were characteristic of $K$. alvarezii crops in the Ubatuba-SP region [32, 38].

The chemical composition of the brown and red strains grown in May 2013 and June 2013 was evaluated (Table 1). The chemical compositions of the samples varied; the samples are ranked in terms of highest productivity in Table 1. The percentages of total carbohydrate, ash, sulfate groups, proteins, insoluble aromatics, galacturonic acid, hydroxymethylfurfural, and the lipid content of the samples ranged from 51.6-55.8, 14.6-17.2, $9.6-10.8,2.3-3.8,1.5-3.4,0.9-1.5,2.8-4.5$, and $0.2-$ $1.3 \%$, respectively. The summative data were in the range of $88.7-95.9 \%$. Note that the soluble aromatics were not quantified because the UV spectrum of protein, derived

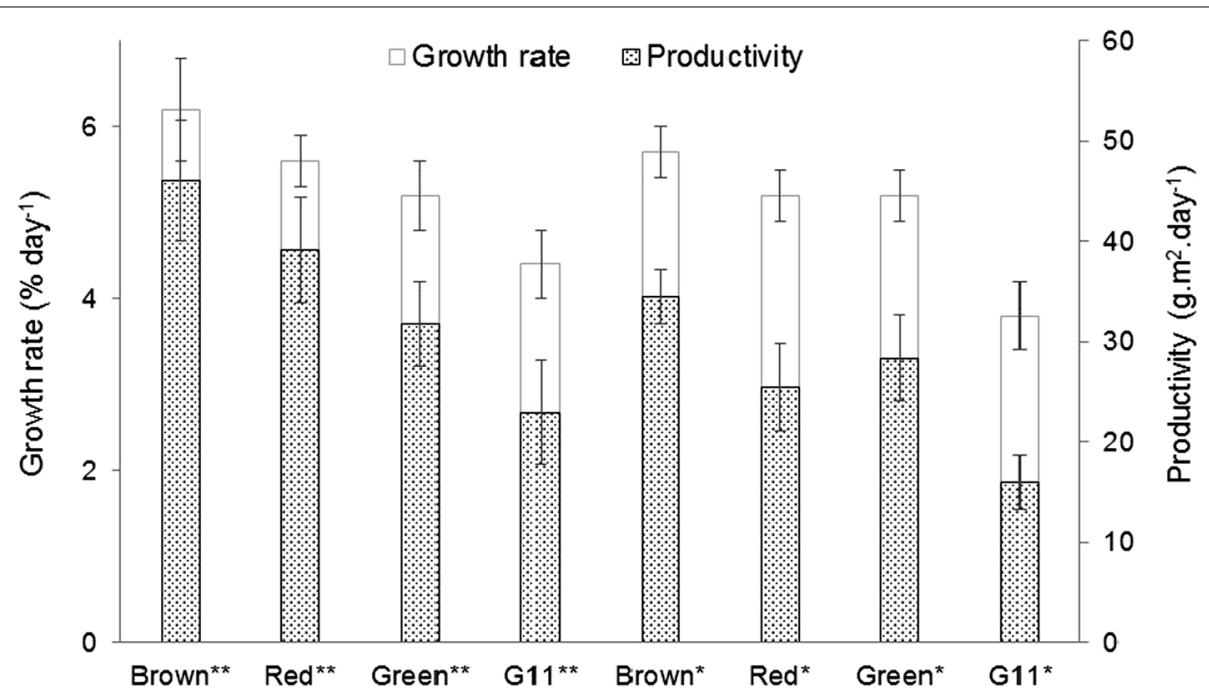

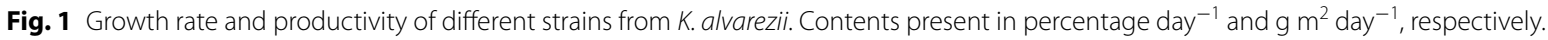
Asterisks Cultivation for June 2013, Two asterisks cultivation for May de 2013. All reported data are the average values followed by their standard deviations 
Table 1 Components of chemical composition of different strains from $K$. alvarezii

\begin{tabular}{|c|c|c|c|c|c|c|c|c|c|}
\hline Strains & $\begin{array}{l}\text { Total } \\
\text { carbohydrates (\%) }\end{array}$ & Ashes (\%) & $\begin{array}{l}\text { Sulfate } \\
\text { groups (\%) }\end{array}$ & Proteins (\%) & $\begin{array}{l}\text { Insoluble } \\
\text { aromatics (\%) }\end{array}$ & AG (\%) & HMF (\%) & Lipids (\%) & Sum (\%) \\
\hline Brown ${ }^{* *}$ & $53.4 \pm 1.2^{a, b, c, e, f}$ & $14.6 \pm 0.1^{a}$ & $9.6 \pm 0.2^{a, b, c, d, e, f}$ & $3.8 \pm 0.5$ & $2.4 \pm 0.1$ & $0.9 \pm 0.1$ & $4.5 \pm 0.3$ & $0.5 \pm 0.1$ & 91.6 \\
\hline $\operatorname{Red}^{* *}$ & $52.3 \pm 1.0^{b, e, f}$ & $16.0 \pm 0.1^{b, c, d, e}$ & $10.1 \pm 0.3^{b, c, d, e, f}$ & $2.5 \pm 0.3$ & $1.5 \pm 0.2$ & $1.0 \pm 0.1$ & $4.1 \pm 0.2$ & $0.6 \pm 0.1$ & 88.7 \\
\hline Brown ${ }^{*}$ & $54.6 \pm 0.4^{\mathrm{c}, \mathrm{d}, \mathrm{e}}$ & $16.5 \pm 0.1^{c, d, e}$ & $9.6 \pm 0.8^{c, d, e, f}$ & $2.5 \pm 0.5$ & $3.0 \pm 0.2$ & $1.2 \pm 0.1$ & $3.6 \pm 0.4$ & $0.5 \pm 0.1$ & 91.5 \\
\hline Green $^{*}$ & $55.8 \pm 0.4^{d}$ & $16.4 \pm 0.2^{\mathrm{d}, \mathrm{e}}$ & $10.7 \pm 0.1^{d, e, f}$ & $3.1 \pm 0.3$ & $2.9 \pm 0.2$ & $1.5 \pm 0.1$ & $3.4 \pm 0.2$ & $1.3 \pm 0.1$ & 95.9 \\
\hline $\operatorname{Red}^{*}$ & $52.7 \pm 1.0^{e, f}$ & $16.6 \pm 0.2^{e}$ & $10.1 \pm 0.1^{e, f}$ & $2.5 \pm 0.3$ & $3.4 \pm 0.1$ & $1.3 \pm 0.1$ & $2.8 \pm 0.3$ & $0.6 \pm 0.1$ & 90.0 \\
\hline $\mathrm{G} 11^{*}$ & $51.6 \pm 0.3^{f}$ & $17.2 \pm 0.1^{f}$ & $10.8 \pm 0.8^{f}$ & $2.3 \pm 0.3$ & $2.7 \pm 0.2$ & $1.3 \pm 0.2$ & $4.3 \pm 0.1$ & $0.2 \pm 0.1$ & 90.4 \\
\hline
\end{tabular}

Contents present in percentage ( $\mathrm{g} / 100 \mathrm{~g}$ of original material in dry basis)

(*) Cultivation for June 2013, $\left({ }^{* *}\right)$ cultivation for May 2013

$A G$ galacturonic acid, HMF hydroximethylfurfural

All reported data are the average values followed by their standard deviations. In each column, the values with the same superscript letters do not differ among themselves at significance level of 0.05 (Tukey test, Software GraphPad Instat)

from amino acids, overlaps with that of the soluble aromatics. Compounds that absorb in the visible region were also detected (data not shown), but these compounds were not quantified due to lack of a quantified, known standard. However, these compounds might account for part of the 'undetermined compound' content.

Carbohydrate constituted the main component for all strains studied. The average total carbohydrate content determined herein was $53.4 \%$, whereas that documented in the literature for the same species is around $63 \%$ [26, 43]. The reported total carbohydrate content of the species Gelidium amansii (red macroalgae) is around $78 \%$ $[10,29]$. The highest total carbohydrate values (54.6 and $55.8 \%$, respectively) were obtained for the brown and green strains, both grown in June 2013 (Table 1). Ash accounted for the second major component of the samples (Table 1). The brown strain grown in May $2013 \mathrm{had}$ the lowest ash content (14.6\%) and the G11 strain grown in June 2013 had the highest ash content (17.2\%). The ash contents of the other strains of the same species did not differ significantly. On average, the observed ash contents were similar to that reported in the literature for the same species [26, 43]. The species Gelidium amansii (red macroalgae) was recently reported to have an ash content of around $6 \%[10,29]$. Notably, after harvesting algal biomass from the sea, washing with water at $25^{\circ} \mathrm{C}$ is required to remove excess salts that accumulate in the biomass. The average ash content of the different strains evaluated in this study before washing was $50 \%$. Sulfate groups constituted the third largest component (Table 1). The average content of sulfate groups in carrageenan originating from $K$. alvarezii was $10.1 \%$, and there was no significant difference among the strains. The other components assessed were proteins, insoluble aromatics, galacturonic acid, hydroxymethylfurfural, and lipids (Table 1). The average protein content was $2.8 \%$, while that documented in the literature for the same species was around $4.5 \%[26,43]$. The brown strain cultivated in May 2013 had the highest protein content (3.8\%), while the G11 strain cultivated in June 2013 had the lowest protein content $(2.3 \%)$. The species Gelidium amansii (red macroalgae) was recently reported to have a protein content of around $14.5 \%[10,29]$. The insoluble aromatic content has not been documented in the literature and was quantified via hydrolysis with sulfuric acid [30]. However, $K$. alvarezii contains proteins; thus, the protein content of the acid hydrolysate was assayed. There was no significant difference between the protein content of the biomass (Table 1) and the corresponding acid hydrolysate (data not shown). All fractions retained on the filters that did not contain protein were considered as insoluble aromatics. The average insoluble aromatic content was $2.6 \%$. Galacturonic acid was detected in small amounts at an average of $1.2 \%$.

Hydroxymethylfurfural was also detected in the strains since this compound is derived from oxidation of glucose and galactose under acidic and high temperature conditions. However, the average value was $2.5 \%$, which is similar to that obtained from the hydrolysis process employing sulfuric acid and lignocellulosic biomass [44]. Only traces of furfural were detected in the samples (data not shown). The last component detected in the strains was lipid. The average lipid content was $0.6 \%$, similar to that documented for the same species $(0.7 \%)$ [24, 38]. The lipid content of the species Gelidium amansii (red macroalgae) was recently reported to be around $1 \%[10$, 29].

In addition to the total carbohydrates, the profile of monomeric sugars in the $K$. alvarezii strains was also analyzed (Fig. 2). HPLC-MS analysis indicated the presence of anhydrogalactose, galactose, glucose, mannose, and xylose. In addition, rhamnose was detected in 
trace amounts due to the small portion of pectin in $K$. alvarezii biomass, derived from galacturonic acid [45] (Table 1). Arabinose and cellobiose were not detected in the samples. The percentage of galactose, anhydrogalactose, glucose, mannose, and xylose in the strains ranged from 13.8-14.5, 17.3-21.6, 11.3-13.0, 0.9-1.6, and $0.5-0.8 \%$, respectively (Fig. 2). Thus, the major polysaccharides found in K. alvarezii were galactans (from galactose and anhydrogalactose), followed by glucans (from glucose). The metal composition of the different strains under investigation was further analyzed by assay of the ash from $K$. alvarezii (Table 1; Fig. 3). The main metals detected were potassium, calcium, and sodium (Fig. 3). In addition to these metals, traces of manganese, iron, and silicon were detected. Notably, the concentrations of potassium, calcium, and sodium in the strains ranged from 28.6 to $60.8,2.7-5.7$, and $0.5-5.1 \mathrm{mg} \mathrm{g}^{-1}$, respectively (Fig. 3). The strains grown in June 2013 had higher

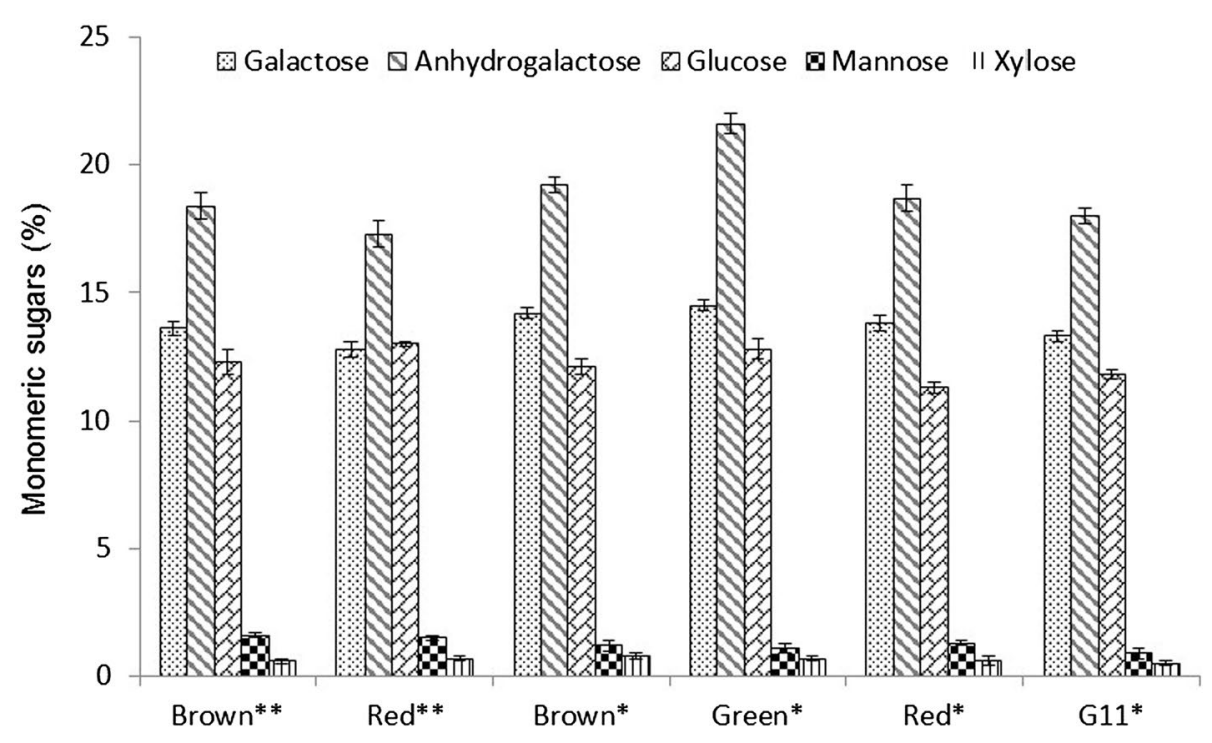

Fig. 2 Sugar composition monomeric different strains of K. alvarezii. Contents present in percentage ( $\mathrm{g} / 100 \mathrm{~g}$ of original material in dry basis). Asterisks Cultivation for June 2013, Two asterisks cultivation for May 2013. All reported data are the average values followed by their standard deviations

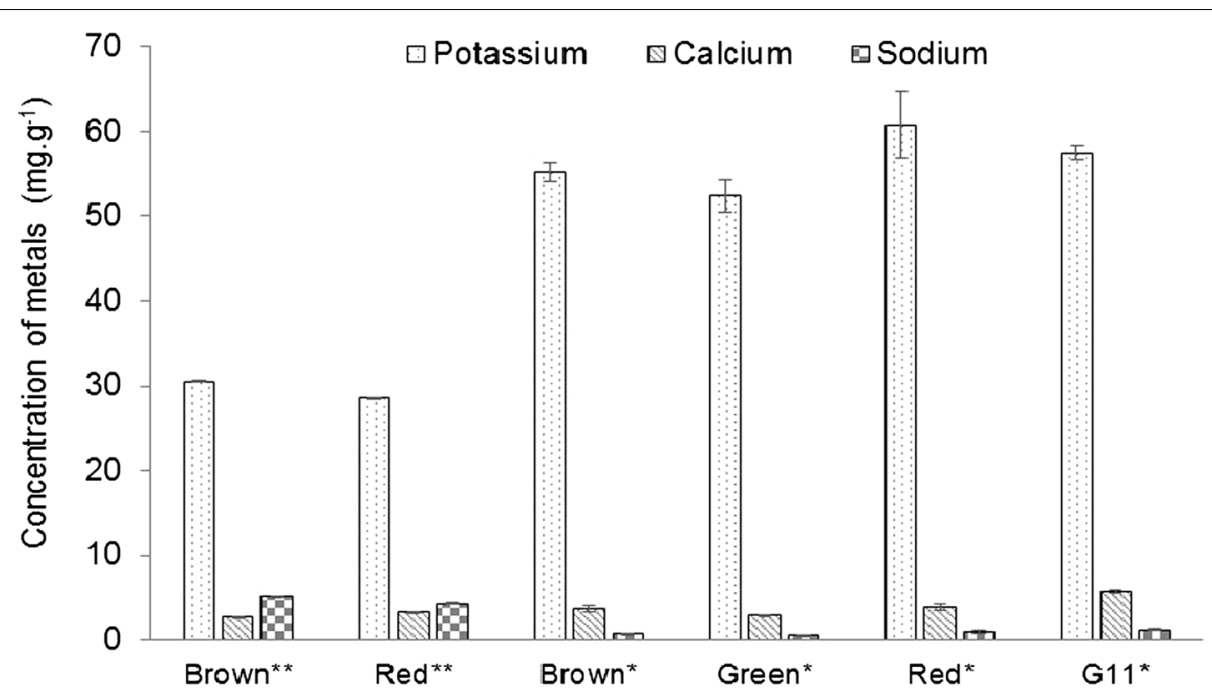

Fig. 3 Composition of metals of different strains of K. alvarezii. Contents present in mass (milligrams/grams of original material in dry basis). Asterisks Cultivation for June 2013, Two asterisks cultivation for May 2013. All reported data are the average values followed by their standard deviations 
potassium and lower sodium contents than those grown in May 2013 (Fig. 3).

\section{Carrageenan processing and obtaining residue from two selected strains}

The brown and red strains grown in May 2013 were selected due to their higher productivity and growth rates. Another parameter that could have been used was the total carbohydrate content (Table 1), but these values did not vary greatly between the strains, thus the productivity and growth rates were taken into account. The yields of biomass from the brown and red strains treated with $6 \% \mathrm{KOH}$ solution (w/v) were 89.3 and $89.5 \%$, respectively (Table 2 ). The treated biomass became clearer compared to untreated biomass (Fig. 4a, b). Among all the components detected in the biomass (Table 1) from the four $K$. alvarezii strains, the following components were chosen for analysis of the chemical composition for the two selected strains: galactan, glucan, ash, proteins, insoluble aromatics, and sulfate groups (Table 2). The values of these components were similar for the untreated biomass and treated biomass, with the exception of the protein content (which was reduced by approximately $90 \%$ ) and the ash (which showed an accumulation of approximately $17 \%$ ) in the case of treated biomass. The dissolution of proteins is common in alkaline medium, while the accumulation of ash reflects the adsorption of potassium in the material upon treatment with $6 \% \mathrm{KOH}(\mathrm{w} / \mathrm{v})$ [46] (Table 2).

The yields of extracted carrageenan and the residue obtained from the treated biomass were, respectively, 63.5 and $23 \%$ for the brown strain and 60 and $27.8 \%$ for the red strain (Table 2). The carrageenan was obtained as a translucent and soft material, while the residue was an opaque and hard material (Fig. 4c, d). The content of galactan, glucan, ash, protein, insoluble aromatics, and sulfate groups in the residues from the brown and red strains was 7.2 and $9.7 \%$ (galactan), 54.6 and $50.2 \%$ (glucan), 14.9 and $10.1 \%$ (ash), 0.5 and $0.4 \%$ (protein), 3.9 and $3.2 \%$ (insoluble aromatics), and 8.4 and $8.7 \%$ (sulfate groups), respectively (Table 2). The galactan content in the residue from the strains had lower and higher glucan contents than that of the samples treated with $6 \% \mathrm{KOH}$ $(\mathrm{w} / \mathrm{v})$ (Table 2). The galactan, ash, protein, insoluble aromatics, and sulfate groups contents of carrageenan from the brown and red strains were 42.6 and $46.6 \%$ (galactan),

Table 2 Yield and chemical composition of brown and red strains from $K$. alvarezii before and after treatment with $6 \%$ $(w / v) \mathrm{KOH}$ and subsequently extracted with hot water (carrageenan and residue production)

\begin{tabular}{|c|c|c|c|c|c|c|c|c|}
\hline Samples & Strain & $\begin{array}{l}\text { Yield of sample } \\
\text { ( } \mathrm{g} / 100 \mathrm{~g} \text { of material) (\%) }\end{array}$ & Galactan (\%) & Glucan (\%) & Ashes (\%) & Proteins (\%) & $\begin{array}{l}\text { Insoluble } \\
\text { aromatics (\%) }\end{array}$ & $\begin{array}{l}\text { Sulfate } \\
\text { groups (\%) }\end{array}$ \\
\hline \multicolumn{9}{|c|}{ Components of samples (\% on pulp basic) } \\
\hline Untreated & Brown & 100 & $33.0 \pm 0.4$ & $12.7 \pm 0.5$ & $14.6 \pm 0.1$ & $3.8 \pm 0.5$ & $2.4 \pm 0.1$ & $9.6 \pm 0.2$ \\
\hline Treated with $\mathrm{KOH}$ & & $89.3 \pm 0.9$ & $32.4 \pm 0.8$ & $13.5 \pm 0.6$ & $21.7 \pm 0.1$ & $0.5 \pm 0.1$ & $2.2 \pm 0.2$ & $10.4 \pm 0.3$ \\
\hline Residue & & $23.0 \pm 0.5$ & $7.2 \pm 0.3$ & $54.6 \pm 0.4$ & $14.9 \pm 0.1$ & $0.5 \pm 0.1$ & $3.9 \pm 0.1$ & $8.4 \pm 0.1$ \\
\hline Carrageenan & & $63.5 \pm 0.6$ & $42.6 \pm 0.9$ & nd & $24.2 \pm 0.1$ & $0.3 \pm 0.1$ & $1.1 \pm 0.1$ & $13.3 \pm 0.2$ \\
\hline Untreated & Red & 100 & $31.3 \pm 0.8$ & $13.5 \pm 0.1$ & $16.0 \pm 0.2$ & $2.5 \pm 0.3$ & $1.5 \pm 0.2$ & $10.1 \pm 0.3$ \\
\hline Treated with $\mathrm{KOH}$ & & $89.5 \pm 0.5$ & $35.6 \pm 1.2$ & $14.1 \pm 0.7$ & $21.6 \pm 0.1$ & $0.4 \pm 0.1$ & $1.8 \pm 0.2$ & $10.6 \pm 0.5$ \\
\hline Residue & & $27.8 \pm 1.2$ & $9.7 \pm 0.2$ & $50.2 \pm 1.2$ & $10.1 \pm 0.1$ & $0.4 \pm 0.1$ & $3.2 \pm 0.5$ & $8.7 \pm 0.1$ \\
\hline Carrageenan & & $60.0 \pm 1.5$ & $46.6 \pm 1.1$ & nd & $28.5 \pm 0.3$ & $0.3 \pm 0.1$ & $1.4 \pm 0.3$ & $14.0 \pm 0.3$ \\
\hline $\begin{array}{l}\text { Commercial car- } \\
\text { rageenan }\end{array}$ & - & - & $32.5 \pm 0.8$ & $0.4 \pm 0.1$ & $34.8 \pm 0.1$ & $0.5 \pm 0.2$ & $0.7 \pm 0.1$ & $12.8 \pm 0.1$ \\
\hline \multicolumn{9}{|c|}{ Components of samples (\% of original material) } \\
\hline Untreated & Brown & 100 & $33.0 \pm 0.4$ & $12.7 \pm 0.5$ & $14.6 \pm 0.1$ & $3.8 \pm 0.5$ & $2.4 \pm 0.1$ & $9.6 \pm 0.2$ \\
\hline Treated with $\mathrm{KOH}$ & & $89.3 \pm 0.9$ & $28.9 \pm 0.8$ & $12.0 \pm 0.6$ & $19.4 \pm 0.1$ & $0.4 \pm 0.1$ & $1.9 \pm 0.2$ & $9.3 \pm 0.3$ \\
\hline Residue & & $23.0 \pm 0.5$ & $1.7 \pm 0.3$ & $12.6 \pm 0.4$ & $3.4 \pm 0.1$ & $0.1 \pm 0.1$ & $0.9 \pm 0.1$ & $1.9 \pm 0.1$ \\
\hline Carrageenan & & $63.5 \pm 0.6$ & $27.0 \pm 0.9$ & nd & $15.4 \pm 0.1$ & $0.2 \pm 0.1$ & $0.7 \pm 0.1$ & $8.4 \pm 0.2$ \\
\hline Untreated & Red & 100 & $31.3 \pm 0.8$ & $13.5 \pm 0.1$ & $16.6 \pm 0.2$ & $2.5 \pm 0.3$ & $1.5 \pm 0.2$ & $10.1 \pm 0.3$ \\
\hline Treated with $\mathrm{KOH}$ & & $89.5 \pm 0.5$ & $31.8 \pm 1.2$ & $12.6 \pm 0.7$ & $19.3 \pm 0.1$ & $0.4 \pm 0.1$ & $1.6 \pm 0.2$ & $9.5 \pm 0.5$ \\
\hline Residue & & $27.8 \pm 1.2$ & $2.7 \pm 0.2$ & $13.9 \pm 1.2$ & $2.8 \pm 0.1$ & $0.1 \pm 0.1$ & $0.9 \pm 0.5$ & $2.4 \pm 0.1$ \\
\hline Carrageenan & & $60.0 \pm 1.5$ & $28.0 \pm 1.1$ & nd & $17.1 \pm 0.3$ & $0.2 \pm 0.1$ & $0.8 \pm 0.3$ & $8.4 \pm 0.3$ \\
\hline
\end{tabular}

Contents present in percentage ( $\mathrm{g} / 100 \mathrm{~g}$ of basic and original material in dry basis)

Cultivation for May 2013, commercial carrageenan = Sigma and nd = not detected. All reported data are the average values followed by their standard deviations. Pulp basic (data representing the biomass without considering a mass balance) and original material (data corrected considering the yield of the process, i.e., performing a mass balance) 

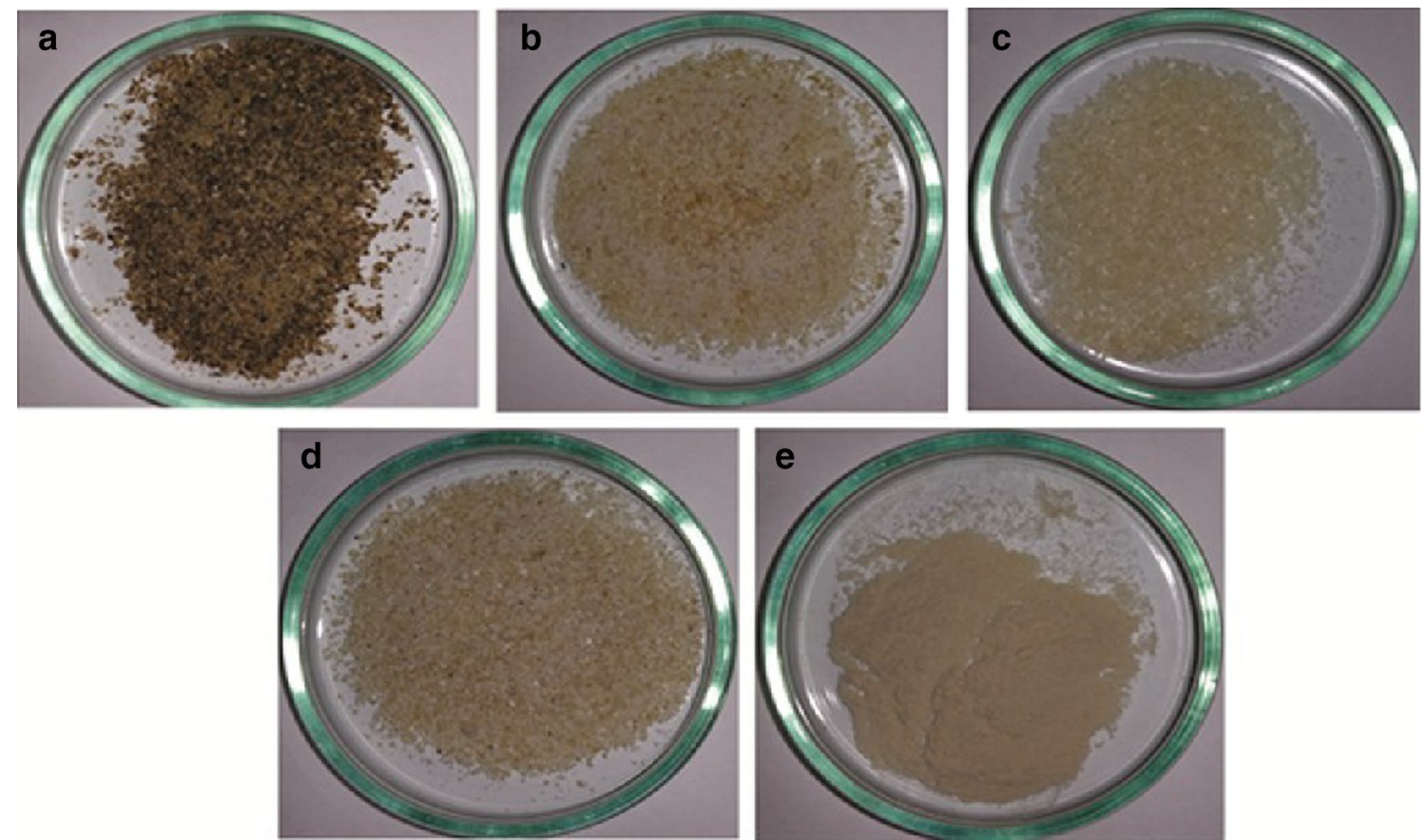

Fig. 4 Residual solids of brown strain cultivation for May 2013 after treatment with $6 \% \mathrm{KOH}(\mathrm{w} / \mathrm{v})$ and subsequently extraction of semi-refined carrageenan. a Untreated material, b treated with $\mathrm{KOH} 6 \%(\mathrm{w} / \mathrm{v})$ material, c semi-refined carrageenan, $\mathbf{d}$ residue and e commercial carrageenan

24.2 and $28.5 \%$ (ash), 0.3 and $0.3 \%$ (protein), 1.1 and $1.4 \%$ (insoluble aromatics), and 13.3 and $14.0 \%$ (sulfate groups), respectively (Table 2 ). The compositional profile of carrageenan obtained from both strains was similar to that of commercial carrageenan; the main components detected were galactan, ash, and sulfate groups (Table 2). For direct comparison of the chemical composition of the residue and the macroalgal material treated with $6 \% \mathrm{KOH}$, a mass balance was required. The galactan, ash, protein, insoluble aromatics, and sulfate group contents of the residues from the brown and red strains were reduced by 94 and $91 \%$ (galactan), 82 and $83 \%$ (ash), $75 \%$ for both (protein), 53 and $44 \%$ (insoluble aromatics), and 80 and $75 \%$ (sulfate groups), respectively. However, the glucan content in the residue was not reduced for either strain (Table 2). After completing the process of obtaining carrageenan (treatment with $6 \% \mathrm{KOH}$ solution and subsequent extraction with hot water), the yields of carrageenan and residue were, respectively, 56.7 and $20.5 \%$ for the brown strain and 53.6 and $24.8 \%$ for the red strain. The overall yields of semi-refined carrageenan were similar to those reported in the literature [27, 32].

The metal content of the samples treated with $6 \% \mathrm{KOH}$ solution $(w / v)$ and extracted with hot water was also assessed. The three main metals evaluated were potassium, calcium, and sodium (Table 3). The chemical composition of the original material treated with $6 \% \mathrm{KOH}$ solution (w/v) for both strains indicated accumulation of potassium (approximately $20 \%$ ) and reduction of the sodium content (by approximately $73 \%$ ). The calcium content was similar to that of the untreated samples (Table 3). The potassium, calcium, and sodium contents of the residues from the brown and red strains were 7.2 and $9.7 \%$ (potassium), 54.6 and $50.2 \%$ (calcium), and 14.9 and $10.1 \%$ (sodium), respectively. Assessment of the metal content of the carrageenan extracted from the brown and red strains revealed lower levels of metals compared to that found in the residue. Specifically, the potassium, calcium, and sodium contents of the carrageenan from the brown and red strains were 0.5 and $0.4 \%$ (potassium), 3.9 and $3.2 \%$ (calcium), and 8.4 and $8.7 \%$ (sodium), respectively (Table 3 ). For direct comparison of the chemical composition of the residue and the macroalgal material treated with $6 \% \mathrm{KOH}$, a mass balance was required. From the mass balance, the metal contents of the residues from the brown and red strains were, respectively, reduced as follows: potassium (86.6 and $84.7 \%$ ), calcium (70.0 and $45.8 \%$ ), and sodium (61.5 and $58.3 \%$ ) (Table 3 ).

\section{Enzymatic hydrolysis of fractions from K. alvarezii}

Direct enzymatic hydrolysis of the untreated and treated (with $6 \% \mathrm{KOH}$ ) materials and the residue can provide an indication of their digestibility and the suitability for macroalgae bioethanol production processes [25, $26,30]$. Such processes are also applied to extraction of 
Table 3 Yield and metals composition of brown and red strains from $K$. alvarezii before and after treatment with $6 \%$ $(w / v) \mathrm{KOH}$ and subsequently extracted with hot water (carrageenan and residue production)

\begin{tabular}{|c|c|c|c|c|c|}
\hline Samples & Strains & $\begin{array}{l}\text { Yield of sample } \\
\text { (g/100 } \mathrm{g} \text { of material) (\%) }\end{array}$ & $\begin{array}{l}\text { Potassium } \\
\left(\mathrm{mg} \mathrm{g}^{-1}\right)\end{array}$ & $\begin{array}{l}\text { Calcium } \\
\left(\mathrm{mg} \mathrm{g}^{-1}\right)\end{array}$ & $\begin{array}{l}\text { Sodium } \\
\left(\mathrm{mg} \mathrm{g}^{-1}\right)\end{array}$ \\
\hline \multicolumn{6}{|c|}{ Components of samples (mg g ${ }^{-1}$ on pulp basic) } \\
\hline Untreated & Brown & 100 & $30.5 \pm 0.01$ & $2.7 \pm 0.01$ & $5.1 \pm 0.01$ \\
\hline Treated with $\mathrm{KOH}$ & & $89.3 \pm 0.9$ & $42.7 \pm 0.01$ & $3.4 \pm 0.01$ & $1.5 \pm 0.08$ \\
\hline Residue & & $23.0 \pm 0.5$ & $22.3 \pm 0.07$ & $3.8 \pm 0.06$ & $2.3 \pm 0.04$ \\
\hline Carrageenan & & $63.5 \pm 0.6$ & $53.5 \pm 0.01$ & $2.7 \pm 0.01$ & $1.2 \pm 0.01$ \\
\hline Untreated & Red & 100 & $28.6 \pm 0.01$ & $3.3 \pm 0.02$ & $4.3 \pm 0.05$ \\
\hline Treated with $\mathrm{KOH}$ & & $89.5 \pm 0.5$ & $36.5 \pm 0.02$ & $2.7 \pm 0.01$ & $1.3 \pm 0.04$ \\
\hline Residue & & $27.8 \pm 1.2$ & $18.2 \pm 0.04$ & $4.0 \pm 0.01$ & $2.0 \pm 0.06$ \\
\hline Carrageenan & & $60.0 \pm 1.5$ & $48.6 \pm 0.02$ & $2.6 \pm 0.01$ & $1.2 \pm 0.01$ \\
\hline Commercial carrageenan & - & - & $72.8 \pm 0.3$ & $25.8 \pm 0.2$ & $8.6 \pm 0.1$ \\
\hline \multicolumn{6}{|c|}{ Components of samples ( $\mathrm{mg}^{-1}$ of original material) } \\
\hline Untreated & Brown & 100 & $30.5 \pm 0.01$ & $2.7 \pm 0.01$ & $5.1 \pm 0.01$ \\
\hline Treated with $\mathrm{KOH}$ & & $89.3 \pm 0.9$ & $38.1 \pm 0.01$ & $3.0 \pm 0.01$ & $1.3 \pm 0.08$ \\
\hline Residue & & $23.0 \pm 0.5$ & $5.1 \pm 0.07$ & $0.9 \pm 0.06$ & $0.5 \pm 0.04$ \\
\hline Carrageenan & & $63.5 \pm 0.6$ & $34.0 \pm 0.01$ & $1.7 \pm 0.01$ & $0.8 \pm 0.01$ \\
\hline Untreated & Red & 100 & $28.6 \pm 0.01$ & $3.3 \pm 0.02$ & $4.3 \pm 0.05$ \\
\hline Treated with $\mathrm{KOH}$ & & $89.5 \pm 0.5$ & $32.7 \pm 0.02$ & $2.4 \pm 0.01$ & $1.2 \pm 0.04$ \\
\hline Residue & & $27.8 \pm 1.2$ & $5.0 \pm 0.04$ & $1.1 \pm 0.01$ & $0.5 \pm 0.06$ \\
\hline Carrageenan & & $60.0 \pm 1.5$ & $29.1 \pm 0.02$ & $1.5 \pm 0.01$ & $0.7 \pm 0.01$ \\
\hline
\end{tabular}

Contents present in mass (milligrams/grams of basic and original material in dry basis)

Cultivation for May 2013 and commercial carrageenan = Sigma. All reported data are the average values followed by their standard deviations. Pulp basic (data representing the biomass without considering a mass balance) and original material (data corrected considering the yield of the process, i.e., performing a mass balance)

carrageenan from $K$. alvarezii. Therefore, a mixture of commercial cellulases was used herein to hydrolyze the fractions to obtain monomeric sugars.

The glucose concentration in the untreated and treated materials and the residue from the brown and red strains after a $72 \mathrm{~h}$ enzymatic hydrolysis period were 3.2 and $2.8 \mathrm{~g} \mathrm{~L}^{-1}$ (untreated), 3.2 and $2.8 \mathrm{~g} \mathrm{~L}^{-1}$ (treated), and 13.7 and $11.5 \mathrm{~g} \mathrm{~L}^{-1}$ (residue), respectively (Fig. 5a, b). In most cases, the glucan conversion after $72 \mathrm{~h}$ of enzymatic hydrolysis was found to be 100 \% (Fig. 5c, d). Enzymatic hydrolysis of the residues produced the highest concentrations of glucose given that the residues were rich in glucan (Table 2). The maximum rate of hydrolysis of the residues was $1.8 \mathrm{~g} \mathrm{~L}^{-1} \mathrm{~h}^{-1}$, whereas the hydrolysis rates of the untreated and treated samples were $0.3 \mathrm{~g} \mathrm{~L}^{-1} \mathrm{~h}^{-1}$. The high rate of hydrolysis of the residues is associated with its greater capacity to adsorb cellulases due to the glucan-rich nature of the residues (Fig. 5a, b; Table 2). The commercial enzyme extract could hydrolyze the glucans present in all fractions studied without any recalcitrance of the material (Fig. 5c, d). Galactase was not present in the commercial enzymes used for hydrolysis, and the untreated and treated fractions remained rich in galactans (Tables 1,2). Since galactase activity was not detected for the enzymes used, the polysaccharide fraction comprising galactans was not hydrolyzed.

\section{Conclusions}

In summary, the current evaluation of four different $K$. alvarezii strains demonstrated differential rates of productivity and growth; nevertheless, all strains had comparable total carbohydrate levels, the main component found in $K$. alvarezii biomass. The main carbohydrate polymers were galactan and glucan. Other important components were ash (mainly comprised calcium, potassium, and sodium) and sulfate groups.

Semi-refined carrageenan and its residue were successfully obtained from the two selected strains. Upon enzymatic hydrolysis, the residue yielded high concentrations of glucose, with complete conversion of glucan. These results highlight the viability of this byproduct of carrageenan extraction as a monomeric sugar for the eventual production of bioethanol. Since this residue is considered waste and not a food source, this method would be a fourth generation model for the production of biofuels. In summary, we have demonstrated a novel aspect to the biorefining of $K$. alvarezii for developing not only carrageenan, but also the bioproduct glucose. Such insights 

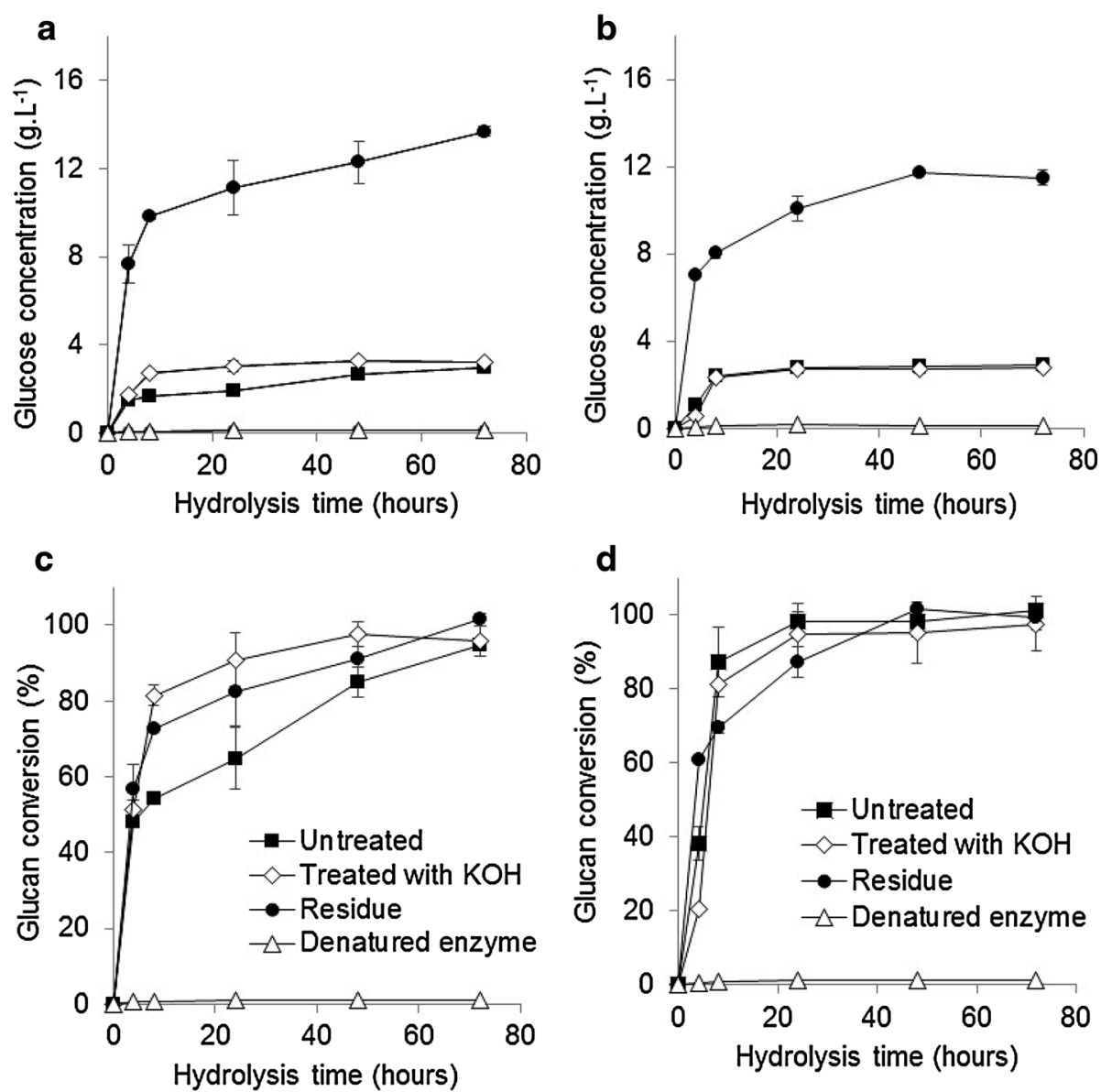

Fig. 5 Glucose concentration and glucan conversion over time for enzymatic hydrolysis from K. alvarezii fractions cultivation for May 2013. a Glucose concentration of brown strain. b Glucose concentration of red strain. c Glucan conversion of brown strain. d Glucan conversion of red strain. (square filled) untreated material, (lozenge open) treated with $\mathrm{KOH} 6 \%$ (w/v) material, (ball filled) residue and (triangle open) residue plus enzyme denature. All symbols apply to the graphs a-d. All reported data are the average values followed by their standard deviations

can further advance this field towards better design of biofuel production strategies.

\section{Abbreviations}

FPU: filter paper unit; HPLC/MS: liquid chromatography/mass spectrophotometry; HPLC: high-performance liquid chromatography; UV: ultraviolet; ESI: electrospray ionization; GHG: greenhouse gas; GW: global warming; SP: São Paulo; SD: standard deviation.

\section{Authors' contributions}

FM, EGSC and FRPC performed chemical analyses, enzymatic hydrolysis of samples and data interpretation. VCG provided the experimental algae strains, performed field trials, determined the agronomic productivity data, data interpretation and reviewed the manuscript. LEO and RM participated in the design of the study, data interpretation and reviewed the manuscript. All authors read and approved the final manuscript.

\section{Author details}

${ }^{1}$ Departamento de Bioprocessos e Biotecnologia, Faculdade de Ciências Farmacêuticas-FCF, UNESP-Univ Estadual Paulista, 14800-903 Araraquara, SP, Brazil. ${ }^{2}$ Departamento de Alimentos e Nutrição, Faculdade de Ciências Farmacêuticas-FCF, UNESP-Univ Estadual Paulista, 14800-903 Araraquara, SP, Brazil. ${ }^{3}$ Departamento de Engenharia Química, Escola de Engenharia de Lorena, USP-Universidade de São Paulo, CP 116, 12602-810 Lorena, SP Brazil. ${ }^{4}$ Instituto de Pesca-Núcleo de Pesquisa e Desenvolvimento do Litoral Norte-Agência Paulista de Pesquisa Agropecuária-Secretaria de Agricultura e Abastecimento do Estado de São Paulo, São Paulo, Brazil.

\section{Acknowledgements}

FAPESP (Contract Number 2014/05969-2), CNPq (Contract Number 440385/2014-8), PROPe-UNESP (Contract Number 506) and Programa de Apoio ao Desenvolvimento Científico da Faculdade de Ciências Farmacêuticas da UNESP-PADC (Contract Number 2013/19-1) supported this work. We appreciate also the support the PADC by providing resources for the English revision of the paper.

\section{Availability of supporting data}

We provide support if necessary data for publication of the article.

\section{Competing interests}

The authors declare that they have no competing interests.

\section{Funding}

FAPESP (Contract Number 2014/05969-2), CNPq (Contract Number 440385/2014-8), PROPe-UNESP (Contract Number 506) and Programa de Apoio ao Desenvolvimento Científico da Faculdade de Ciências Farmacêuticas da UNESP-PADC (contract number 2013/19-1) funding this work. 
Received: 18 March 2016 Accepted: 31 May 2016

Published online: 10 June 2016

\section{References}

1. Mata TM, Martins AA, Caetano NS. Microalgae for biodiesel production and other applications: a review. Renew Sustain Energy Rev. 2010;14:217-32

2. Hayashi L, Reis PR. Cultivation of the red algae Kappaphycus alvarezii in Brazil and its pharmacological potential. Braz J Pharmacogn. 2012;22:748.

3. Zodape ST, Mukherjee S, Reddy MP, Chaudhary DR. Effect of Kappaphycus alvarezii (Doty) Doty ex silva. extract on grain quality, yield and some yield components of wheat (Triticum aestivum L.). Int J Plant Prod. 2009;3(2):1735-8043.

4. Gelli V, Barbieri E: Cultivo e aproveitamento da macroalga Kappaphycus alvarezii para pequenos maricultores. Aquicultura no Brasil: Novas Perspectivas. In: Brito PAM, Brito JRM, editors. Pedro \& João; 2015. p. 641-58.

5. Li Y, Horsman M, Wu N, Lan CQ, Dubois-Calero N. Biofuels from microalgae. Biotechnol Prog. 2008;24(4):815-20.

6. Nigam PS, Singh A. Production of liquid biofuels from renewable resources. Prog Energy Combust Sci. 2011. doi:10.1016/j.pecs.2010.01.003.

7. Champagne P. Feasibility of producing bio-ethanol from waste residues: a Canadian perspective feasibility of producing bio-ethanol from waste residues in Canada. Resour Conserv Recycl. 2007;50:211-30.

8. Brinkhuis BH, Levine HG, Schlenk GG, Tobin S. Laminaria cultivation in the far east and north America. In: Bird KT, Benson PH, editors. Seaweed cultivation for renewable resources. Amsterdam: Elsevier; 1987. p. 107-46.

9. Lewandowski L, Scurlock JMO, Lindvallc E, Christoud M. The development and current status of perennial rhizomatous grasses as energy crops in the US na Europe. Biomass Bioenergy. 2003:25:335-61.

10. Wei N, Quarterman J, Jin Y. Marine macroalgae: an untapped resource for producing fuels and chemicals. Trends Biotechnol. 2013;31:2.

11. Horn SJ, Aasen IM, Østgaard K. Production of ethanol from mannitol by Zymobacter palmae. J Ind Microbiol Biotechnol. 2000;24:51-7.

12. Goh CS, Lee KT. A visionary and conceptual macroalgae-based thirdgeneration bioetanol (TGB) biorefinery in Sabah, Malaysia as an underlay for renewable and sustainable development. Renew Sustain Energy Rev. 2010;12:842-8

13. Amin S. Review on biofuel oil and gas production processes from microalgae. Energy Convers Manage. 2009;50:1834-40.

14. Pulz O, Gross W. Valuable products from biotechnology of microalgae. Appl Microbiol Biotechnol. 2004;65:635-48.

15. Lang X, Dalai AK, Bakhshi NN, Reaney MJ, Hertz PB. Preparation and characterization of bio-diesels from various bio-oils. Bioresour Technol. 2001;80:53-62.

16. Chiaramonti D. Bioethanol: role and production technologies. In: Ranalli $P$, editor. Improvement of crop plants for industrial end uses. Berlin: Springer; 2007. p. 209-51.

17. Matsumoto M, Yokouchi H, Suzuki N, Ohata H, Matsunaga T. Saccharification of marine microalgae using marine bacteria for ethanol production. Appl Biochem Biotechnol. 2003;105-108:247-54.

18. Harun R, Danquah MK, Forde GM. Microalgal biomass as a fermentation feedstock for bioethanol production. J Chem Technol Biotechnol. 2010:85:199-203.

19. Kim S, Dale BE. Global potential bioethanol production from wasted crops and crop residues. Biomass Bioenerg. 2004;26:361-75.

20. Adams JM, Gallagher JA, Donnison IS. Fermentation study on Saccharina latissima for bioethanol production considering variable pre-treatments. J Appl Phycol. 2009;21:569-74.

21. Barrow C, Shahidi F. Marine nutraceuticals and functional foods. Boca Raton: CRC Press; 2008

22. Gayral P, Cosson J. Connaitre et Reconnaitre les Algues Marines. Rennes: Ouest-France; 1986. p. 38-44.

23. Perez R, Kaas R, Campello F, Arbault S, Barbaroux O. La Culture Des Algues Marines dans le Monde. Ifremer. 1992;148-177:227-66.

24. Yoon JJ, Kim YJ, Kim SH, Ryu HJ, Choi JY, Kim GS, Shin MK. Production of polysaccharides and corresponding sugars from red seaweed. Adv Mater. 2010;93-94:463-6.
25. Hargreaves PL, Barcelos CA, Costa ACA, Junior NP. Production of ethanol $3 G$ from Kappaphycus alvarezii: evaluation of different process strategies. Bioresour Technol. 2013;134:257-63.

26. Meinita MDN, Yong YK, Kang GT, Jeong GT, Koo HM, Park SM, Yong YK. Bioethanol production from the acid hydrolysate of the carrageenophyte Kappaphycus alvarezii (cottonii). J Appl Phycol. 2012;24:857-62.

27. Ruiz HA, Jasso RMR, Fernandez BD, Vicente AA, Teixeira JA. Hydrothermal processing, as an alternative for upgrading agriculture residues and marine biomass according to the biorefinery concept: a review. Renew Sustain Energy Rev. 2013;21:35-51.

28. Wang X, Liu X, Wang G. Two-stage hydrolysis of invasive algal feedstock for ethanol fermentation. J Integr Plant Biol. 2011;53(3):246-52.

29. Park JH, Hong JY, Jang HC, Oh SG, Kim SH, Yoon JJ, Kim YJ. Use of Gelidium amansii as a promising resource for bioethanol: a practical approach for continuous dilute-acid hydrolysis and fermentation. Bioresour Technol. 2012:108:83-8

30. Khambhaty Y, Mody K, Gandhi MR, Thampy S, Maiti P, Brahmbhatt H, Eswaran K, Ghosh PK. Kappaphycus alvarezii as a source of bioetanol. Bioresour Technol. 2012;103:180-5.

31. Goes HG, Reis RP. Temporal variation of the growth, carrageenan yield and quality of Kappaphycus alvarezii (Rhodophyta, Gigartinales) cultivated at Sepetiba bay, southeastern Brazilian coast. J Appl Phycol. 2012;24:173-80.

32. Hayashi L, Oliveira EC, Bleicher-Lhonneur G, Boulenguer P, Pereira RTL, Seckendorff RV, Shimoda VT, Leflamand A, Vallée P, Critchley AT. The effects of selected cultivation conditions on the carrageenan characteristics of Kappaphycus alvarezii (Rhodophyta, Solieriaceae) in Ubatuba Bay São Paulo, Brazil. J Appl Phycol. 2007;19:505-11.

33. Yong YS, Yong WTL, Anton A. Analysis of formulae for determination of seaweed growth rate. J Appl Phycol. 2013;25:1831-4

34. Masarin F, Gurpilhares DB, Baffa DCF, Barbosa MHP, Carvalho W, Ferraz A Milagres AMF. Chemical composition and enzymatic digestibility of sugarcane clones selected for varied lignin content. Biotechnol Biofuels. 2011:4:1.

35. Ferraz A, Baeza J, Rodriguez J, Freer J. Estimating the chemical composition of biodegraded pine and eucalyptus wood by DRIFT spectroscopy and multivariate analysis. Bioresour Technol. 2000;74:201-12.

36. Dubois M, Gilles KA, Hamilton JK, Rebers P, Smith F. Colorimetric method for determination of sugars and related substances. Anal Chem. 1956;28:350-6

37. Yun EJ, Kim HT, Cho KM, Yu S, Kim S, Cho I, Kim KH. Pretreatment and saccharification of red macroalgae to produce fermentable sugars. Bioresour Technol. 2016:199:311-8.

38. Hayashi L, Paula EJ, Chow F. Growth rate and carrageenan analyses in four strains of Kappaphycus alvarezii (Rhodophyta, Gigartinales) farmed in the subtropical Waters of São Paulo State, Brazil. J Appl Phycol. 2007;19:393-9.

39. Matsuhiro B. Aislamiento y caracterización de ficocoloides. In: Alveal K, Ferrario ME, Oliveira EC, Sar E, editors. Manual de Métodos Ficológicos. Universidad de Concepción: Concepción; 1995. p. 658-74.

40. Craigie JS, Leigh C. Carrageenans and agars. In: Hellebust JA, Craigie JS, editors. Handbook of phycological methods. Cambrige: Cambrige University Press: 1978. p. 109-31.

41. Hames B, Scarlata C, Sluiter A. Determination of protein content in Biomass. Laboratory Analytical Procedure (LAP). 2008. http://www.nrel.gov/ biomass/analytical_procedures.html\#

42. Sluiter A, Hames B, Ruiz R, Scarlata C, Sluiter J, Templeton D. Determination of ash in biomass. Laboratory Analytical Procedure (LAP). 2005. http://www.nrel.gov/biomass/analytical_procedures.html\#.

43. Abd-Rahim F, Wasoh H, Zakaria MR, Ariff A, Kapri R, Ramli N, Siew-Ling L. Production of high yield sugars from Kappaphycus alvarezii using combined methods of chemical and enzymatic hydrolysis. Food Hydrocoll. 2014;42:309-15.

44. Sluiter JB, Ruiz RO, Scarlata CJ, Sluiter AD, Templeton DW. Compositional analysis of lignocellulosic feedstocks. 1. Review and description of methods. J Agric Food Chem. 2010:58:9043-53.

45. O'Rourke C, Gregson T, Murray L, Sadler IH, Fry SC. Sugar composition of the pectic polysaccharides of charophytes, the closest algal relatives of land-plants: presence of 3-O-methyl-D-galactose residues. Ann Bot. 2015;116:225-36.

46. Hartree EF. Determination of protein: a modification of the Lowry method that gives a linear photometric response. Anal Biochem. 1972;48:422-7. 